\title{
Effects Of Age, Body Mass Index, Complete Blood Count Parameters, and Biochemical Parameters on Stable COPD Patients
}

\section{Stabil KOAH Hastalarında Yaş, Vücut Kitle İndeksi, Tam Kan Sayımı ve Biyokimyasal Parametrelerin Etkileri}

\author{
DMuhammed Emin Düz'1, Aydın Balcı² \\ 1 Medical Biochemistry' Amasya Sabuncuoğlu Şerefeddin Training and Research Hospital, Amasya, Turkey \\ ${ }^{2}$ Departman of Chest Diseases, Health Sciences University Medical Faculties, Afyonkarahisar, Turkey
}

\begin{abstract}
Aim: Chronic obstructive pulmonary disease (COPD) is worldwide and mainly affects the elderly. It is often impossible to define COPD with specific lines, and it has no complete cure procedure, mostly established by guidelines. The GOLD guideline uses a sectional COPD evaluation approach to group patients by symptoms and former history of exacerbations. The concurrent detection of various biomarkers reflecting different pathobiological pathways might help recognize patients with an increased risk of death. Studies showed that obesity is related to decreased lung function in the general population due to respiratory mechanics, muscular discomfort, and breath control.

Material and Method: Ninety patients with COPD, whose mean age was 62 , and $74 \%$ were male, were divided into four groups as $A, B, C$, and D according to the GOLD classification, were included in our study. Analyses were conducted to investigate the association between biochemical parameters, BMI, age, gender, and disease severity, according to GOLD subgroups.

Results: It has been demonstrated that COPD patients are generally over the age of 40 and age correlates with the severity of the disease consistent with previous studies. Our study has shown that COPD usually occurs over the age of 40 , and there is a relationship between advanced age and the severity of COPD.

Conclusion: Our results are consistent with previous studies where COPD patients are usually over 40 years old, and age is linked to disease severity. While the BMI values of the patients in group $B$ were higher than those of group $A$, it was compatible with studies showing the relationship between obesity and severity of COPD; being higher than $C$ and $D$ groups was consistent with the studies revealing the obesity paradox. Crp, Procalcitonin, Sedimentation, Calcium, Magnesium levels, and other complete blood count values showed no significant difference between GOLD groups.
\end{abstract}

Keywords: Body mass index, complete blood count parameters, COPD

\section{Öz}

Amaç: Kronik obstrüktif akciğer hastalığı $(\mathrm{KOAH})$ dünya çapında görülür ve esas olarak yaşlıları etkiler. KOAH'ı belirli çizgilerle tanımlamak genellikle imkansızdır ve çoğunlukla kılavuzlarla belirlenmiş tam bir tedavi prosedürü yoktur. Global Initiative For Chronic Obstructive Lung Disease (GOLD) hastaları semptomlara ve eski alevlenme öyküsüne göre gruplandırmak için bölümsel bir $\mathrm{KOAH}$ değerlendirme yaklaşımı kullanır. Farklı patobiyolojik yolları yansıtan çeşitli biyobelirteçlerin eşzamanlı tespiti, artmış ölüm riski olan hastaların tanınmasına yardımcı olabilir. Çalışmalar obezitenin, solunum mekaniği, kas rahatsızlıkları ve akciğer fonksiyonları üzerine olumsuz etkileri olduğunu göstermiş̧ir.

Gereç ve Yöntem: Çalışmamıza ortalama yaşı 62,\% 74'ü erkek olan 90 KOAH'lı hasta dahil edildi.Hastalar GOLD sınıflamasına göre A, B, C ve D olmak üzere dört gruba ayrıldı. Biyokimyasal parametreler,Vücut Kitle indeksi (VKI), yaş, cinsiyet ve hastalık şiddeti arasındaki ilişkiyi GOLD alt gruplarına göre araştırmak için analizler yapıldı.

Bulgular: KOAH Grup B'deki hastaların VKI değerleri A grubuna göre daha yüksek iken, obezite ile $\mathrm{KOAH}$ şiddeti arasında anlamlı ilişki tespit edildi. GOLD C ve D gruplarında VKI değerinin yüksek olması obezite paradoksunu ortaya koyan çalışmalarla uyumluydu. C-reactive protein (CRP), Prokalsitonin, Sedimantasyon, Kalsiyum, Magnezyum seviyeleri ve diğer tam kan sayımı değerleri GOLD grupları arasında anlamlı bir fark göstermedi.

Sonuç: Çalışmamız KOAH'ın genellikle 40 yaşın üzerinde ortaya çıktığını, ileri yaş ile $\mathrm{KOAH}$ ın şiddeti arasında iliş̧ki olduğunu göstermiştir. Grup B'deki hastaların VKi değerleri A grubuna göre daha yüksek iken, obezite ile $\mathrm{KOAH}$ şiddeti arasındaki ilişkiyi gösteren çalışmalarla uyumluydu; C ve D gruplarından yüksek olması obezite paradoksunu ortaya koyan çalışmalarla uyumluydu. Crp, Prokalsitonin, Sedimantasyon, Kalsiyum, Magnezyum seviyeleri ve diğer tam kan sayımı değerleri GOLD grupları arasında anlamlı bir fark göstermedi.

Anahtar Kelimeler: Vücut kitle indeksi, tam kan parametreleri, $\mathrm{KOAH}$ 


\section{INTRODUCTION}

Chronic obstructive pulmonary disease (COPD) is a commonplace disease worldwide and mainly affects the elderly. Global authorities 2017 report by; COPD, often caused by severe exposure to damaging particles or gases, persevering airflow restriction, and alveolar abnormalities. Chronic airflow restriction, which is characteristic of COPD, is a small airway disease (obstructive bronchiolitis) that varies from person to person. It develops as a result of parenchymal destruction (emphysema). Although these pathologies are not always together, they evolve at different rates over time. Chronic inflammation constricts small airways and destroys the lung parenchyma. Loss of small airways also causes airflow restriction and contributes to mucociliary dysfunction. COPD is a multicomponent and variable disease. Therefore, it is often impossible to define COPD with specific lines, and it has no complete cure procedure, mostly established by guidelines. The Global Initiative for Chronic Obstructive Lung Disease (GOLD) system classifies airflow restriction into stages. The GOLD guideline uses a sectional COPD evaluation approach to group patients by symptoms and former history of exacerbations. ${ }^{[1]}$ Prognosis changes with several factors, including genetic predispositions, environmental factors, comorbidities, and acute attacks. Even though short-term survival is contingent on the overall seriousness of the acute attacks, long-term survival is intent on by the severeness of COPD and the existence of comorbid conditions. Commonly, the prognosis depends on the FEV1 pulmonary function testing. Scientists showed a significant correlation between increased FEV1 and lower risk of COPD aggravation. ${ }^{[2]}$

Higher levels of multiple biomarkers are related to mortality in stable COPD patients. The concurrent detection of various biomarkers reflecting different pathobiological pathways might help recognize patients with an increased risk of death. [3] Many biomarkers separately associated with increased risk of death, and a few had the more distant supply to mortality prediction with known clinical variables. ${ }^{[4]}$ Although because COPD is a complex and heterogeneous disease with differing phenotypes, the aim of finding a single biomarker of COPD is a dream for now. ${ }^{[5]}$ Besides, biomarkers don't have to come from the lungs to be functional in predict prognosis. ${ }^{[6]} \mathrm{A}$ panel of predictive biomarkers is needed to understand ongoing disease. $^{[7]}$ Aggravations in chronic obstructive pulmonary disease (COPD) are significant contributors to worsening lung function, impaired quality of life, emergency healthcare use, and COPD-related mortality. COPD aggravations are heterogeneous in terms of airway inflammation and etiology.

About $60 \%$ of COPD patients have blood eosinophil counts of $\geq 2 \%$, which appears to be associated with an increased risk of aggravations. However, the association between blood eosinophil counts at stable disease and COPD aggravations in the subsequent year are incompletely understood. Even though the eosinophil evaluation is currently in discussion, eosinophil count is important as biomarkers to design the treatment. Specifically, eosinophils help assess which patients may benefit from inhaled corticosteroid therapy, especially concerning aggravation prevention. ${ }^{[8]}$ Additionally, a large epidemiologic study found bilirubin concentrations negatively associated with COPD incidence. ${ }^{9]}$ C-reactive protein (CRP) binds bacteria, oxidized lipids, and apoptotic cells and enables their destruction via the immune system. Moderately increased serum CRP levels associates with inflammation in atherosclerosis and therefore increased risk of coronary heart disease and myocardial infarction. Supporting proof now suggests that increased serum CRP levels also associate with lung inflammation in stable COPD. Therefore, serum CRP could be a predictor of future COPD outcomes. ${ }^{[10]}$ Procalcitonin (PCT) is more sensitive and specific in differentiating bacterial infection from noninfectious inflammation. PCT is a polypeptide that producing from neuroendocrine cells of the thyroid and lungs. The high level of PCT found in serum during severe sepsis, and septic shock reflects bacterial infections. Recently, PCT guidance provides clinically relevant information and safely reduce antibiotic use in patients with respiratory illness. Delay in diagnosis and treatment of COPD aggravations and its associated comorbidities increases the mortality risk, but timely recognition of these patients and intervention is essential. ${ }^{[11-13]}$

Obesity, distinguished by extreme body fat accumulation, can be assessed by body mass index (BMI). Obesity is a frequent comorbidity of COPD, with approximately ranges from $6 \%$ to $54 \%$. The severity of COPD depends on the degree of airway restriction, which is an indicator of lung dysfunction. Body weight affects lung function independent of tobacco use. Many studies have shown that obesity is related to decreased lung function in the general population due to gas exchange, respiratory mechanics, muscular discomfort, and breath control. Obesity could also strengthen to lessen lung function through chronic low-grade inflammation. ${ }^{[14]}$ The authors proposed that obesity in patients with COPD might advance to worse COPD-related health outcomes such as acute exacerbation of COPD and dyspnea scores. ${ }^{[15]}$ Therefore, it is accepted that obesity in patients with COPD should be treated with weight loss via exercise, which is useful for reformed lung function and diminished complications. Nonetheless, a metaanalysis by Cao et al. demonstrated that overweight and obese patients with COPD had a decreased risk of all-cause mortality. [16] This circumstance is known as the "obesity paradox," which is decribed as an opposite relationship between survival and obesity and has been monitored in numerous chronic diseases, as well as type II diabetes mellitus, stroke, and chronic kidney disease. The connection between obesity and mortality in patients with COPD has been controversial, but evidence has indicated a dose-response relationship between BMI and mortality. ${ }^{[17]}$

Some studies have determined that younger patients with COPD show more depression and anxiety symptoms and low quality of life than older ones. This information is consistent with research on a diversity of chronic illnesses that specify that young age disease is associated with more psychological distress and lessens life quality. More distant, the influence of age on patient outcomes may vary based on educational and social supplies. The effect of age may be substantial between 
individuals with fewer resources. Psychosocial interventions can pick out the most in need if authorities can recognize persons' attributes for whom a young age presents a higher risk for adverse outcomes. ${ }^{[18]}$

This study investigated whether BMI, age, complete blood count, and various biochemical parameters are associated with disease severity in COPD patients. We used the GOLD index to determine the severity of the disease.

\section{MATERIALS AND METHODS}

Ninety patients with COPD, whose mean age was 62 , and $74 \%$ were male, diagnosed and treated Afyonkarahisar university of health sciences Medical Faculty, Department of Pulmonology, Afyon, Turkey were included in our study. According to the GOLD classification, the patients were divided into four groups as A, B, C, and D. Pulmonary function test data, complete blood count values, Crp, Pct, sedimentation, calcium, and magnesium parameters of the patients were compared according to the groups. Univariable and multivariable analyses were conducted to investigate the association between biochemical parameters, BMI, age, gender, and disease severity, according to GOLD subgroups. Groups were adjusted to describe potential confounding factors: smoking status, pef25-75 value, asthma history, moderate exacerbations, or one or more severe exacerbations during one year. Standard distribution variables calculated using the ANOVA test. We analyzed variables as mean \pm standard error (SE), mean \pm standard deviation (SD). P-values below 0.05 were considered significant. Statistical analyses were performed using JASP 0.14 statistical software (JASP team, Amsterdam, Netherlands).

\section{RESULTS}

According to the GOLD classification, a statistically significant difference was found between mean age values of group $A$ and groups $C$ and $D(p<0.001, p=0.015)$, and the statistically insignificant difference between group $B(p=0.129)$ (Figure 1). Groups $C$ and $D$ were older than group $A$. The mean $B M I$ values of group $B$ were significantly higher than groups $A, C$, and $D$ $(p=0.047, p=0.026, p=0.021)$ shown in Figure 2. Neutrophil percentage values were significantly different between the groups ( $p=0.004)$, and group $C$ had a significantly higher percentage of neutrophils than group A $(p=0.026)$. Similarly, monocyte percentage values were significantly different

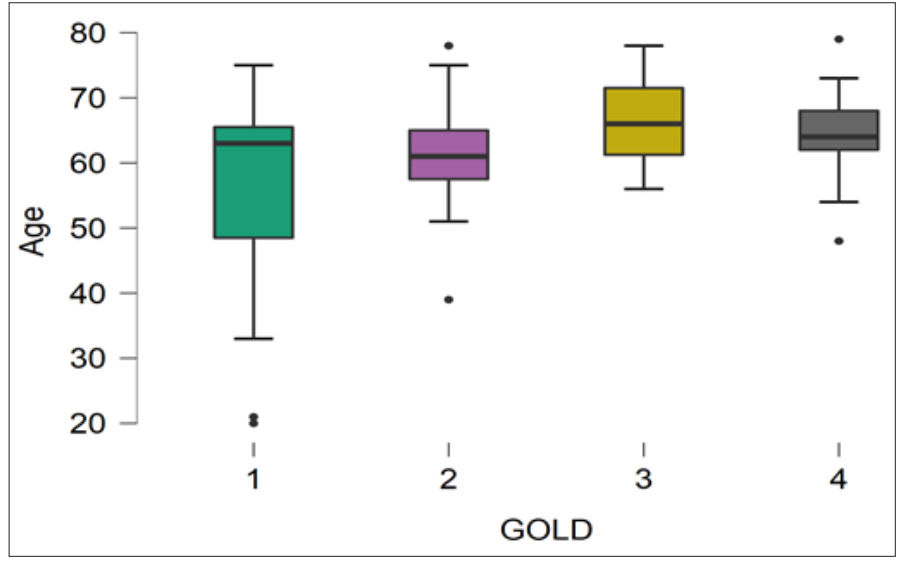

Figure 1. Relationship between age and GOLD groups. $A, B, C$ and $D$ groups are shown as 1,2,3 and 4 .

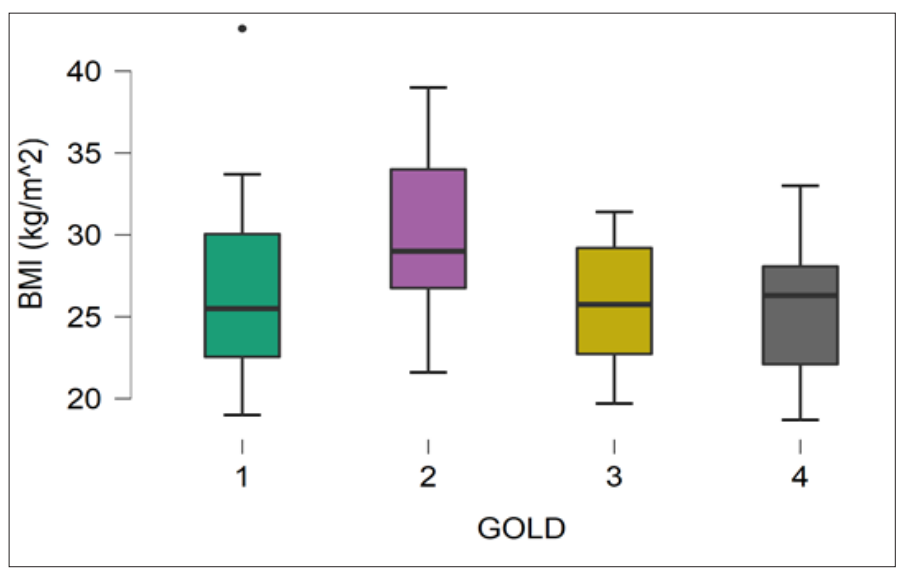

Figure 2. Relationship between BMI and GOLD groups. A, B, C and D groups are shown as 1,2,3 and 4 .

between the groups ( $p=0.048$ ), and group $C$ had a significantly lower percentage of monocytes than group A $(p=0.028)$. However, platelet levels were significantly different between the groups $(p=0.004)$, and group $C$ had significantly lower platelet levels than group $A(p=0.006)$. The groups' eosinophil percentage values were $3.49,2.41$, and $2.35,3.16$, respectively, but no statistical correlation could be established between them. Crp, Procalcitonin, Sedimentation, Calcium, Magnesium levels, and other complete blood count values showed no significant difference between GOLD groups. Descriptive statistics are given in Table 1.

\begin{tabular}{|c|c|c|c|c|c|}
\hline GOLD & A & B & C & D & p-Value \\
\hline Age & $54.3 \pm 15.7$ & $61.8 \pm 9.1$ & $66.3 \pm 6.8$ & $64.3 \pm 7.9$ & $<0.001$ \\
\hline Eosinophile(\%) & $3.32 \pm 1.74$ & $2.39 \pm 1.44$ & $2.60 \pm 1.29$ & $3.05 \pm 2.57$ & $=0.004$ \\
\hline $\operatorname{Crp}(\mathrm{mg} / \mathrm{L})$ & $2.064 \pm 1.32$ & $0.57 \pm 0.26$ & $1.86 \pm 1.59$ & $2.03 \pm 1.97$ & $=0.867$ \\
\hline Sedimentation ( $\mathrm{mm} / \mathrm{hour}$ ) & $36.1 \pm 13.2$ & $24.1 \pm 13.3$ & $27.5 \pm 14.3$ & $26.8 \pm 17.4$ & $=0.643$ \\
\hline
\end{tabular}




\section{DISCUSSION}

COPD is generally diagnosed after the age of 45 and is mostly acknowledged disease of the elderly. It's thought to be an advancing sickness that takes many years to develop. As stated by the Burden of Obstructive Lung Disease (BOLD) Initiative, the approximate international prevalence of stage II or worse COPD is recently $10.1 \%$ in persons aged 40 years and older. However, it should be kept in mind that in some genetic conditions such as alpha-1 anti-trypsin deficiency, COPD can be seen under the age of $40 .{ }^{[19]}$ According to the results we obtained in our study, the mean age was $61+/-10$ years, and the average ages, according to the groups, were 55, 61, 64, and 59, respectively. Our results are consistent with previous studies where COPD patients are usually over 40 years old, and age is linked to disease severity. The longer individuals have particular risk factors for COPD; they would more probably develop the disease as an older adult. There is accumulating confirmation that aging characteristics are notable features of COPD. These aging characteristics have been defined in several sub-groups of COPD patients, different lung compartments, and a range of cell types. So, they could commit to different COPD phenotypes. A better considerate of the principal differences and similarities between normal lung aging and the pathology of COPD may develop our comprehension of the mechanisms utilizing COPD pathology, especially in those patients that produce the most vigorous form of COPD at a relatively young age. ${ }^{[20]}$

While spirometry is used for diagnosis and degree of COPD intensity concerning the GOLD guidelines, classification of overweight and obesity is based on body mass index (BMI) as described by the World Health Organization (WHO). The prevalence of obesity, designated as BMI $>30 \mathrm{~kg} / \mathrm{m}^{2}$, has increased during the last decades and alters from 10-20\% in most European countries to $32 \%$ in the USA. Obesity has a central role in improving metabolic syndrome and has been determined as a significant risk factor for chronic illnesses like type 2 diabetes mellitus and cardiovascular disease. ${ }^{[21-22]}$ Obesity is associated with respiratory conditions such as obstructive sleep apnoea syndrome and obesity hypoventilation syndrome, and gathering proof proposes a relationship between obesity and asthma. ${ }^{[23]}$ A possible connection between obesity and COPD is also progressively realized, although not much is known about this relation's mechanisms. ${ }^{[24]}$ In patients with COPD, obesity is usually correlated with a heightened risk of mortality; on the other hand, surprisingly, several studies have indicated that being overweight or obese may offer a survival advantage over a fatless phenotype. ${ }^{[25]}$ COPD patients with a reduced BMI lean to have an advanced mortality rate than patients of normal BMI. Individuals that were overweight or obese had a lower risk of mortality, which formed the "obesity paradox." BMI is a simple sign of weight for height and cannot diversify between lean muscle mass metabolically and functionally active and fat mass. Consequently, BMI can be a fallacious index of survival or health outcomes in COPD patients. ${ }^{[26]}$ Our study found that the BMI averages of the patients in the GOLD B group were compatible with obesity and were significantly higher than the other groups. While the BMI values of the patients in group B were higher than those of group $A$, it was compatible with studies showing the relationship between obesity and severity of COPD; being higher than $C$ and $D$ groups was consistent with the studies revealing the obesity paradox. Considering all groups, BMI values were not correlated with COPD severity. At this point, we concluded that BMI values do not correlate with disease severity and prognosis since they do not reflect the amount of muscle mass that is more closely related to the prediction of COPD. Concerning BMI evaluation in COPD, we predict that respiratory muscle amount and activity are more valuable in predicting the disease's clinical course.

Evaluation of COPD is set mainly on clinical presentations, which can be unstable, and due to these, many biomarkers are also appraised. ${ }^{[27]}$ Blood culture has been mostly used as a conventional approach for the detection of any infectious reason. Nonetheless, blood cultures are time-consuming, and it takes days to weeks to specify the microorganism in the blood. Complete blood count analysis like total leukocyte and the neutrophil count is performed in all exacerbation cases and has a restricted significance in the early detection of community-acquired pneumonia. ${ }^{[28]}$ Even though new markers as procalcitonin and pro-adrenomedullin are being interpreted, these markers' quick application is hindered by validation, expenses, and accessibility. ${ }^{[29]}$ Studies indicated the relationship between lymphocyte count, hemoglobin, platelet count, mean platelet volume, platelet distribution width, and reticulocyte distribution width with COPD. ${ }^{[30,31]}$ COPD patients can divide into eosinophilic (peripheral blood eosinophil rate $\geq 2 \%$ ) and neutrophilic (peripheral blood eosinophil rate $<2 \%$ ), and further subdivided according to the place of admission (inpatient, outpatient, or intensive care unit [ICU]) as a sign of disease intensity. ${ }^{[32]}$ Eosinophil percentage values were more outstanding than two in our patient groups, which showed us that we have patients with the eosinophilic type that is a valuable indicator for corticosteroid response. Still, the lack of difference between the groups made it impossible for us to differentiate. Group C had a significantly higher percentage of neutrophils, substantially lower percentage of monocytes, and appreciably lower platelet levels than group A. We could not reach differential values in terms of complete blood count parameters in patients. Whole blood parameters, which are stated to be useful in determining the severity of COPD in the literature, and the practice of using them in proportion to each other, were evaluated based on acute exacerbation cases. We studied these parameters in our patients for general evaluation, not acute exacerbation. Therefore, we could not find values that differentiate in the data according to disease severity. Consequently, we do not see it to evaluate according to these parameters in COPD patients, except for acute attacks. Using the same logic, we better understand why Crp, Procalcitonin, Sedimentation, Calcium, and Magnesium levels do not differ significantly between groups. Although there are many studies on acute exacerbation, there are not enough studies to evaluate patients in general and to predict the severity of the disease, 
and advanced studies, mainly including control groups, are needed. The essential data we have obtained in our study is that; Age and BMI have a significant effect on disease severity and prognosis in patients with COPD, except for acute attacks.

\section{ETHICAL DECLARATIONS}

Ethics Committee Approval: The study was carried out with the permission of Academical Ethics Committee of Afyonkarahisar Health Science Üniversity (Permission granted: 11.09.2020, Decision no: 2020/396).

Informed Consent: All patients signed the free and informed consent form.

Referee Evaluation Process: Externally peer-reviewed. Conflict of Interest Statement: The authors have no conflicts of interest to declare.

Financial Disclosure: This study was supported by Afyonkarahisar health sciences university medical faculties Fund (Project Number: 2020/396).

Author Contributions: All of the authors declare that they have all participated in the design, execution, and analysis of the paper, and that they have approved the final version.

\section{REFERENCES}

1. Global Strategy for the Diagnosis, Management, and Prevention of COPD, Global Initiative for Chronic Obstructive Lung Disease (GOLD) 2017.

2. Zider AD, Wang $X$, Buhr RG, et al. Reduced COPD exacerbation risk correlates with improved FEV1: a meta-regression analysis. Chest. 2017 Sep;152(3):494-501.

3. Stolz D, Meyer A, Rakic J, et al. Mortality risk prediction in COPD by a prognostic biomarker panel. Eur Respir J. 2014 Dec;44(6):1557-70.

4. Stolz D, Christ-Crain M, Morgenthaler NG, et al. Copeptin, C-reactive protein, and procalcitonin as prognostic biomarkers in acute exacerbation of COPD. Chest 2007; 131: 1058-1067.

5. Agustı' A, Edwards LD, Rennard SI, et al. Persistent systemic inflammation is associated with poor clinical outcomes in COPD: a novel phenotype. PLoS One 2012; 7: e37483.

6. Divo M, Cote C, de Torres JP, et al. Comorbidities and risk of mortality in patients with chronic obstructive pulmonary disease. Am J Respir Crit Care Med 2012; 186: 155-161.

7. Kelly E, Owen CA, Pinto-Plata V, et al. The role of systemic inflammatory biomarkers to predict mortality in chronic obstructive pulmonary disease. Expert Rev Respir Med 2013; 7: 57-64.

8. Pascoe S, Locantore N, Dransfield MT, et al. Blood eosinophil counts, exacerbations, and response to the addition of inhaled fluticasone furoate to vilanterol in patients with chronic obstructive pulmonary disease: a secondary analysis of data from two parallel randomized controlled trials. Lancet Respir Med 2015; 3: 435-442.

9. Mannino DM, Tal-Singer R, Lomas DA, et al. Plasma fibrinogen as a biomarker for mortality and hospitalized exacerbations in people with COPD. J COPD F. 2015;2(1):23-34.

10. Gan WQ, Man SFP, Senthilselvan A, Sin DD. Association between chronic obstructive pulmonary disease and systemic inflammation: a systematic review and a meta-analysis. Thorax, 2004;59:574-580.

11. Stolz D, Christ-Crain M, Bingisser R, Leuppi J, Miedinger D, Müller C, et al. Antibiotic treatment of exacerbations of COPD: A randomized, controlled trial comparing procalcitonin-guidance with standard therapy. Chest. 2007;131:9-19.

12. Christ-Crain M, Jaccard-Stolz D, Bingisser R, Gencay MM, Huber PR, Tamm $M$, et al. Effect of procalcitonin-guided treatment on antibiotic use and outcome in lower respiratory tract infections: Cluster-randomised, singleblinded intervention trial. Lancet. 2004;363:600-7.
13. Koutsokera A, Stolz D, Loukides S, Kostikas K. Systemic biomarkers in exacerbations of COPD: The evolving clinical challenge. Chest. 2012;141:396-405.

14. Lacoma A, Prat C, Andreo F, Domínguez J. Biomarkers in the management of COPD. Eur Respir Rev 2009;18(112):96-104.

15. Dahl M. Biomarkers for chronic obstructive pulmonary disease: surfactant protein D and C-reactive protein. Am J Respir Crit Care Med 2008;177(11):1177-1178.

16. Cao C, Wang R, Wang J, Bunjhoo H, Xu Y, Xiong W. Body mass index and mortality in chronic obstructive pulmonary disease: a meta-analysis. PLoS One. 2012;7(8):e43892. doi:10.1371/journal.pone.0043892.

17. Guo Y, Zhang T, Wang Z, et al. Body mass index and mortality in chronic obstructive pulmonary disease: A dose-response meta-analysis. Medicine (Baltimore). 2016;95(28):e4225. doi:10.1097/MD.0000000000004225.

18. Holm KE, Plaufcan MR, Ford DW, et al. The impact of age on outcomes in chronic obstructive pulmonary disease differs by relationship status. $J$ Behav Med. 2014;37(4):654-663. doi:10.1007/s10865-013-9516-7.

19. Buist AS, McBurnie MA, Vollmer WM, et al. International variation in the prevalence of COPD (the BOLD Study): a population-based prevalence study. Lancet 2007;370:741-50.

20. Corry-Anke Brandsma, Maaike de Vries, Rita Costa, Roy R. Woldhuis, Melanie Königshoff, Wim Timens. Lung ageing and COPD: is there a role for ageing in abnormal tissue repair? Eur Respir Rev 2017 26: 170073; DOI: 10.1183/16000617.0073-2017.

21. Rabe KF, Hurd S, Anzueto A, et al. Global strategy for the diagnosis, management, and prevention of chronic obstructive pulmonary disease: GOLD executive summary. Am J Respir Crit Care Med 2007;176:532-55.

22. World Health Organization. Overweight and obesity: a new nutrition emergency? Monitoring the rapidly emerging public health problem of overweight and obesity: the WHO global database on body mass index. SCN News 2004:5-12.

23. Jubber AS. Respiratory complications of obesity. Int J Clin Pract 2004;58:573-80.

24. Poulain M, Doucet M, Major GC, et al. The effect of obesity on chronic respiratory diseases: pathophysiology and therapeutic strategies. CMAJ 2006;174:1293-9.

25. Cebron Lipovec N., Beijers R.J., van den Borst B., Doehner W., Lainscak M. Schols A.M. The Prevalence of Metabolic Syndrome In Chronic Obstructive Pulmonary Disease: A Systematic Review. COPD. 2016;13:399-406.

26. Schols A.M., Broekhuizen R., Weling-Scheepers C.A., Wouters E.F. Body composition and mortality in chronic obstructive pulmonary disease. The American Journal of Clinical Nutrition. 2005;82:53-59.

27. Agapakis DI, Massa EV, Hantzis I et al. The role of mean platelet volume in chronic obstructive pulmonary disease exacerbation. Resp Care 2016; 61: 44-8.

28. Gallego $\mathrm{M}$, Pomares $\mathrm{X}$, Capilla $\mathrm{S}$ et al. $\mathrm{C}$ reactive protein in outpatients with acute exacerbation of COPD; its relationship with microbial etiology and severity. Int'I J COPD 2016; 11: 2633-40.

29. De Jager CPC, Paul TLV Wijk, Mathoera RB, Jongh- Leuvenink JD, Poll TVD, Wever PC. Lymphocytopenia and neutrophil- lymphocyte count ratio predict bacteremia better than conventional infection markers in an emergency care unit. Crit Care 2010; 14: R192.7.

30. Kocak MZ. Evaluation of red cell distribution width levels during acute exacerbation in patients with chronic obstructive pulmonary disease. Biomed Res India 2017; 28: 3009-11.8.

31. Karadeniz G, Aktogu S, Erer OF, Bulac Kir S, Doruk S, Demir M. Evaluation of mean platelet volume and platelet distribution width in patients with chronic obstructive pulmonary disease. Eur Resp J 2015; 46:3984-7.

32. Aksoy E, Karakurt Z, Gungor S, et al. Neutrophil to lymphocyte ratio is a better indicator of COPD exacerbation severity in neutrophilic endotypes than eosinophilic endotypes. Int J Chron Obstruct Pulmon Dis. 2018;13:2721-2730. Published 2018 Sep 4. doi:10.2147/COPD.S170353 